\title{
Well-being and Sustainable Development of Mining Regions: the Universal Basic Income
}

\author{
Oleg Mazavin ${ }^{1,}$, Mikhail Kaz ${ }^{1,2,}{ }^{3}$, and Irina Roshchina ${ }^{1}$ \\ ${ }^{1}$ Tomsk State University, Institute of Economics and management, 634050 Lenin Avenue, 36, \\ Tomsk, Russia \\ ${ }^{2}$ Tomsk Polytechnic University, 634050 Lenin Avenue 30, Tomsk, Russia \\ ${ }^{3}$ Tomsk State University of Control Systems and Radioelectronics, 634050 Lenin Avenue 40, Tomsk, \\ Russia
}

\begin{abstract}
The article presents the results of the analysis of the practice of implementation the concept of universal basic income. It is shown that in estimating the results of a series of experiments in this field, conducted in a number of countries, it is recommended to abandon the approach based on the positivist point of view. For a long time, it dominated science in general and economic research in particular, but it continues to influence many researchers today. This conclusion should be taken into account in the formation of the structure and composition of regions' welfare indices. The research materials are placed in a broad historical context. On the one hand, this made it possible to more vividly present the prerequisites, characteristics and consequences of repeated attempts to introduce universal basic income into the practice of social insurance, undertaken in different countries of the world (Finland, Canada, Kenya, Iran, India, USA). On the other hand, to reveal the possibilities and problems of using universal basic income as a tool to help overcome the dysfunctional development of certain territories, including mining regions.
\end{abstract}

\section{Introduction}

The growth of social inequality in economic theory has traditionally been considered as a negative externality, which along with environmental pollution (environmental factor), has a negative effect on the level of welfare. The welfare impact was quantified in an integral index such as the Index of Sustainable Economic Welfare developed by Daley and Cobb (ISEW) [1]. It was subsequently modified to the Genuine Progress Indicator (GNI). Both are widely used in regional welfare practice [2], [3]. According to the Index of Social Wellbeing of the Regions, developed on their basis M.Yu. Malkina [4], a number of mineral regions of the Russian Federation were included in the disadvantaged category: Kemerovo Region, Komi Republic and others.

The above approach to the study of social well-being is consistent with the principles of the positivist paradigm that has long dominated in science in general and in economic

\footnotetext{
${ }^{*}$ Corresponding author: oleg.mazavin@yandex.ru
} 
research in particular. However, in response to the work of B. Strumpell [5] and A. Campbell [6], the term "subjective economic well-being" penetrated the apparatus of economic research. Subjective economic well-being is determined, for example, by B. Strumpell as a result of social comparison of a person's actual status with his claims, needs and perception of his own position [5] or according to A. Campbell as a financial situation with reference (typical, similar or authoritative) persons. Our study, based on the example of the analysis of the experience of introducing a universal basic income, shows how the practice of carefully following the positivist paradigm inevitably leads to its denial.

\section{Materials and Methods}

The theory of universal basic income was first proposed by Thomas Payne. In Agrarian Justice, published in 1797, he pointed out the need to create a national fund in the United States that would pay $£ 15$ to all citizens over the age of 21 . Justifying the need to pay this amount, he pointed out that everyone had the right to own the land. However, as a result of historical processes, the majority of the population was deprived of this right. Therefore, the payment of a certain amount personally to each citizen at the expense of landowners was a kind of compensation [7].

Subsequently, this phenomenon was enshrined in the concept of "universal basic income". Philippe Van Parijs defined the universal basic income as "income paid by the political community to all its members on an individual basis, without testing needs and employment requirements" [8]. Fifteen pounds sterling, about which T. Payne wrote, certainly correspond the above definition of universal basic income. However, its modern supporters explain the need to pay this income by the fact that it will simplify the cumbersome state social security system in terms of its functions related to the control of neediness, as well as reduce the level of poverty and inequality.

Negative income tax is another tool closely related to universal basic income [9]. However, there is a difference between these concepts: the idea of a negative income tax involves the payment of subsidies if the income falls below a certain threshold. One of the options for negative income tax was proposed by M. Friedman [10]. It provided for the payment of subsidies when income is less than a certain threshold value (in this case, the income received by a citizen, in addition to the subsidy, is also not taxable). However, the amount of the subsidy decreases proportionally to the increase in income.

\section{Results and Discussion}

Let us consider in more detail the experiments on universal basic income and negative income tax, currently being conducted.

Finland. The study of universal basic income was conducted from January 2017 to December 2018. It was attended by 2,000 randomly selected unemployed at the age of 25 58 years. The essence of the experiment was to replace unemployment benefits with basic income. The amount of these payments was 560 euros per person per month and did not depend on any other sources of income that could appear during the study. The remaining social benefits (for example, housing allowance, sickness benefit) were preserved in full. It was impossible to refuse to participate in the experiment, but it stopped if the person moved abroad, joined the armed forces of Finland or started receiving child care benefits.

The official goal of the experiment was to find out whether universal basic income can help increase employment and simplify the social security system. However, first of all, this experiment was aimed at encouraging the employment of the segment of officially 
unemployed people who do not seek to get a job because of the fear of losing unemployment benefit, which is, on average, just 560 euros.

In preparing the study, several options for its implementation were considered, the negative income tax model was rejected due to the lack of a population income register. As a result, the experiment was based on the model of partial universal basic income [11].

The final results of the study will be published in 2019, however, the first preliminary results of the experiment on the use of universal basic income in Finland have already been obtained (Table 1).

Table 1. Preliminary results of the experiment on implementing universal base income in Finland.

\begin{tabular}{|c|c|c|}
\hline Estimated parameter & $\begin{array}{c}\text { Participants of the } \\
\text { experiment }\end{array}$ & Control group \\
\hline $\begin{array}{c}\text { Average time spent on work during the } \\
\text { year, days }\end{array}$ & 49.64 & 49.25 \\
\hline Proportion of workers (of total), \% & 43.7 & 42.85 \\
\hline $\begin{array}{c}\text { Labor income per person per year, } \\
\text { Euro }\end{array}$ & 4230 & 4251 \\
\hline $\begin{array}{c}\text { The proportion of people (of the total } \\
\text { number) who assess their own health } \\
\text { as good, \% }\end{array}$ & 55 & 46 \\
\hline
\end{tabular}

The data indicate that no significant changes have occurred: employment and the amount of income of participants in the experimental and control groups differ a bit. However, according to the results of the survey, the researchers noted that the participants in the experiment considered themselves to be more prosperous, they noted a reduction in stress symptoms, problems with concentration, overall health, as well as a decrease in time spent on bureaucratic red tape [12].

Canada. The government of the Canadian province of Ontario began to study the negative income tax in 2017. It took place in the settlements of Lindsay, Thunder Bay and Hamilton. To participate in the study the residents aged from 18 to 64 years old with low incomes (34 thousand Canadian dollars per year for a single person, or 48 thousand Canadian dollars per year for a married couple) were randomly selected. All participants in the experiment were divided into two groups: the test and control [13].

During the experiment, the following data were evaluated: diet, mental and physical health indicators, employment, skills and living conditions.

The main goal of the experiment was to assess the economic efficiency of introducing negative income tax by reducing the cost of maintaining the bureaucratic apparatus.

The initial plan of the study provided for payments for three years. However, in August 2018 the provincial authorities announced a premature termination of the project in 2019, explaining that the excessive burden on taxpayers.

Kenya. The study of universal basic income was carried out by an independent Give Directly Foundation in Kenya. Give Directly is an international non-governmental organization founded in 2009. It studies the effect of unconditional remittances to poor households in developing countries. [14].

In 2011-2013, a study of unconditional basic income in several villages was conducted in Kenya. All households were divided into three groups in which payments differed: by recipient (men or women), by transfer dates (monthly or one-time), by size (large or small). The purpose of this study was to assess the relative impact of the so-called "unconditional remittances" on social and economic indicators.

In the course of the experiment, households increased their spending on consumption (food), on savings (in the form of purchasing durable goods, investing in animal husbandry and investing in their own employment). The positive results of the study are the lack of an 
increase in the consumption of alcohol and tobacco, as well as the empowerment of women. [15].

India. In 2011-2012, a universal basic income survey was conducted in Madhya Pradesh, India, with the support of UNICEF and the Self-Employed Women's Association of India (SEWA). Each adult was paid 200 rupees per month, each child 100 rupees in eight villages (later payments were increased to 300 and 150 rupees, respectively). A total of about 6,000 people were covered. The comparison group included residents of other villages. The funds were paid individually: first in cash, later to a bank account.

The main goal of the experiment was to evaluate remittances on social and economic indicators. [16].

During the study, the following changes were observed in people's lives [17]: improvement of living conditions; improving nutrition, especially for children, which contributed to improved health and reduced morbidity; increasing school attendance; improving the conditions of women and people with disabilities; development of own business (small shops, workshops, etc.); increase in the number of self-employed; reduction of employment in workplaces with difficult working conditions; debt reduction; increase in savings.

Those covered in the study consumed less alcohol, which can be explained by a decrease in stress as a result of an improvement in the material situation [18]. Also, the researchers noted that the universal basic income scheme in India, due to its transparency and lack of corruption, may be less expensive than the existing system of subsidies.

The universal basic income has already been introduced in two countries: the United States (Alaska) and Iran. The main source of payments is oil revenues in Alaska and Iran.

Iran. The government of Iran introduced in 2011 a universal basic income for all citizens of the country. Its application was the result of the ongoing reform of the subsidy system [19], which was aimed primarily at eliminating non-market pricing principles and improving the efficiency of the economy, as well as a more equitable redistribution of oil rent [20].

The program included several stages, during the implementation of which subsidies to producers of goods, suppliers of services were reduced and prices for subsidized goods and services increased. At the same time, every citizen of Iran was paid a universal basic income as a compensation for price increases. The outcome of the program was to be a complete cessation of subsidies for goods and services. However, during the reform period, prices for subsidized goods increased significantly. For example, the price of bread in 2012 increased by 2 times, for diesel fuel by 9 times, and for some goods the price increase reached $2000 \%$. Consumption of goods and services fell by $10-30 \%$ simultaneously with the rise in prices.

Conducted few studies had not revealed a significant change in the labor market as a result of the implementation of the program [21].

The USA. The United States of America became the first country in the world to start paying its citizens a universal basic income. However, it happens just in one state. The government of the state of Alaska took the initiative to accumulate a portion of oil revenues in a separate fund, which was called the Alaska Permanent Fund in 1976 [22]. Every year, it is replenished with deductions in the amount of $25 \%$ of then royalties received by the state (rental payment of oil producing companies for the right to develop natural resources). This represents about $10 \%$ of the state's total oil revenues, as the lion's share is taxed. The fund's assets are invested in stocks, bonds, real estate, etc. The profit of the fund is distributed in the form of dividends between residents of the state.

Despite the fact that dividends have been distributed for a long time, official studies on the impact of payments on socio-economic indicators, as well as on the labor market, have not been conducted [23]. However, universal basic income programs have support of the 
population. More than $95 \%$ of the population in Alaska have filed applications and receive universal payments.

The analysis shows (Table 2) that of the six countries for which information was collected on the practice of applying the concept of basic income, only one country in the USA (Alaska) does not have data on its impact on the population. In two countries (Kenya, India) the results obtained coincide with the goals set. Only side effects in two countries (Finland, Iran) achieved covered by the concept of "subjective well-being".

Table 2. The purpose and results of the introduction of universal basic income in different countries.

\begin{tabular}{|c|c|c|c|}
\hline Country & $\begin{array}{c}\text { The official goal of } \\
\text { the program }\end{array}$ & $\begin{array}{c}\text { Achievment the } \\
\text { official goal }\end{array}$ & $\begin{array}{c}\text { Achievement of side } \\
\text { effects }\end{array}$ \\
\hline Finland & $\begin{array}{c}\text { Increase } \\
\text { employment }\end{array}$ & No & $\begin{array}{l}\text { Reduced stress; } \\
\text { A sense of greater } \\
\text { well-being and } \\
\text { health }\end{array}$ \\
\hline Canada & $\begin{array}{l}\text { Reducing the cost } \\
\text { of maintaining a } \\
\text { bureaucratic } \\
\text { apparatus }\end{array}$ & $\begin{array}{c}\text { No } \\
\text { (significant increase in } \\
\text { burden on taxpayers) }\end{array}$ & No \\
\hline Kenya & $\begin{array}{l}\text { Assess the effect of } \\
\text { unconditional } \\
\text { income on social } \\
\text { and economic } \\
\text { indicators }\end{array}$ & Yes & $\begin{array}{c}\text { Women's } \\
\text { empowerment }\end{array}$ \\
\hline India & $\begin{array}{l}\text { Assessing the } \\
\text { impact of } \\
\text { remittances on } \\
\text { social and economic } \\
\text { indicators }\end{array}$ & Yes & $\begin{array}{c}\text { Decrease in } \\
\text { incidence; Increase } \\
\text { school attendance }\end{array}$ \\
\hline Iran & $\begin{array}{c}\text { Fair redistribution } \\
\text { of oil rent }\end{array}$ & No & Stress reduction \\
\hline $\begin{array}{l}\text { The USA } \\
\text { (Alaska) }\end{array}$ & $\begin{array}{c}\text { Fair redistribution } \\
\text { of oil rent }\end{array}$ & No data & No data \\
\hline
\end{tabular}

If we exclude from the data information about Alaska, on which no studies were conducted, then the results coincided with the intended purpose and both of them correspond to a positivist approach to understanding social well-being in $40 \%$ of the analyzed countries. However, the results achieved correspond to an understanding of wellbeing as a subjectively perceived phenomenon in $80 \%$ of these countries (see Table 1, column 4). All the above confirms that integral indicators of well-being, based only on objective indicators, report only half of the truth. [24, 25].

\section{Conclusion}

Based on the first results of the experiment on the implementation of universal basic income in the practice of Finnish social services, a number of researchers propose to interrupt it, as it did not have positive results. However, based on the position advocated in this article, such a conclusion is valid only if we consider the results of the experiments conducted in this field exclusively from a positivistic point of view.

Our analysis of the practice of introducing basic income shows how an attempt to approach the improvement of well-being, considering it solely as an objective phenomenon, unexpectedly confirmed the important role of subjective component that plays in it. This 
conclusion is of particular interest of our previous research of single-industry mining regions $[26,27,28]$, as well as the rating calculations presented by the Regional Research Foundation "Regions of Russia". The results show that residents of single-industry towns in general, and the cities of Kemerovo Region (Novokuznetsk, Prokopyevsk) that are closing the rating, in particular, are least satisfied with the social aspects of life and their perception, which is, as it is known, personally loaded.

\section{References}

1. H. E. Daly, J. B. Cobb, For the common good: redirecting the economy toward community, the environment, and a sustainable future (Beacon Press, Boston, 1988)

2. B. Bleys, Sustainability, 5:2, 496-523 (2013)

3. D. C. Andrade, J. R. Garcia, Ecological Economics, 118, 49-56 (2015)

4. M. Malkina, Assessment of Inter-Regional Convergence in the Social Welfare Based on the A. Sen Function: Russian Case Study (Economic and Social, London 2016)

5. B. Strumpel, Economic well-being as an object of social measurement (Organization for Economic Cooperation and Development, Paris, 75-122 1974)

6. A. Campbell, P. E. Converse, W. L. Rodgers, The quality of American life: Perceptions, evaluations, and satisfactions (Russell Sage Foundation, New York, 1976)

7. T. Paine, Agrarian Justice (Palgrave Macmillan, London 2004)

8. P. Parijs, Politics \& Society, 32, 7-39 (2004)

9. M. Bussolo, M. E. Davalos, V. Peragine, R. Sundaram, Toward a New Social Contract (World Bank, Washington, 2018)

10. M. Friedman, Capitalism and freedom (Univ. of Chicago Press, Chicago, 1994)

11. O. Kangas, P. Honkanen, K. Hämäläinen, M. Kanerva, From idea to experiments Final report on alternatives for implementing a basic income experiment (Prime Minister's Office, Helsinki, 2016)

12. O. Kangas, S. Jauhiainen, M. Simanainen, M. Ylikännö, The basic income experiment 2017-2018 in Finland. Preliminary results (Ministry of Social Affairs and Health, Helsinki, 2019)

13. Costing a national guaranteed basic income using the Ontario basic income model (Office of the Parliamentary Budget Officer, Ottawa, 2018)

14. J. Haushofer, J. Shapiro, The Quarterly Journal of Economics, 131, 1973-2042 (2016)

15. J. Haushofer, J. Shapiro, Transfer Program in Kenya, 57, 122 (2013)

16. S. Davala, R. Jhabvala, G. Standing, S. K. Mehta, Basic income: a transformative policy for India (INVA, Calcutta, 2015)

17. G. Standing, Global dialogue, 3, 24-26 (2013)

18. R. Schjoedt, Pathways Perspectives on Social Policy in International Development, 21, 90 (2016)

19. H. Tabatabai, Springer, 5, 17-32 (2012)

20. H. Tabatabai, Iran: A Bumpy Road toward Basic Income (Macmillan, New York, 285300 2012)

21. D. Salehi-Isfahani and M. H. Mostafavi-Dehzooei, Journal of Development Economics, 135, 349-367 (2018) 
22. S. Goldsmith, The Alaska Permanent Fund Dividend: A Case Study in Implementation of a Basic Income Guarantee (BNPA, Sao Paulo 2010)

23. S. Goldsmith, An Experiment in Wealth Distribution, 22, 25 (2002)

24. E.M. Kaz, The European Proceedings of Social and Behavioural Sciences, 19, 291-297 (2017)

25. E.M. Kaz, The European Proceedings of Social and Behavioural Sciences, 7, 295-301 (2016)

26. I.V. Roshina, N.A. Artyukhova, The European Proceedings of Social and Behavioural Sciences, 19, 823-829 (2017)

27. N.A. Artukhova, I.V. Roshchina, G.S. Kalyanova, M.S. Kaz, E3S Web Conf., 41, 04008 (2018)

28. I.V. Roshina, N.A. Artyukhova, The European Proceedings of Social and Behavioural Sciences, 19, 43-50 (2017) 